\title{
Cutting Propagation of Shea (Vitellaria paradoxa C.F. Gaertn) Tree Using Shoot Types and Application of Auxin
}

\author{
J. Yeboah ${ }^{1}$, M. A. D. Segbefia ${ }^{1}$, A. M. Dadzie ${ }^{1}$, F. Padi $^{1}$, S. T. Lowor ${ }^{1}$, V. N. Agene ${ }^{1}$, F. Owusu-Ansah ${ }^{1}$ \\ \& B. Owusu-Ansah ${ }^{1}$ \\ ${ }^{1}$ Cocoa Research Institute of Ghana, Tafo, Akim, Ghana \\ Correspondence: J. Yeboah, Cocoa Research Institute of Ghana, P.O. Box 8, Tafo, Akim, Ghana. Tel: \\ 233-244-111-441. E-mail: jypyeboah@yahoo.com
}

Received: August 23, 2020

doi:10.5539/jas.v12n12p213

\author{
Accepted: October 20, $2020 \quad$ Online Published: November 15, 2020 \\ URL: https://doi.org/10.5539/jas.v12n12p213
}

\begin{abstract}
The shea is a medium-sized fruit tree indigenous of Sudano-sahelian zone of Africa with great economic potential and ecological components. Planting by seed takes a long time to fruit because of its slow growth. Factors affecting its development among other things are physiological and biochemical. The $2 \times 2$ factorial experiment set up in the rainy season was arranged in a randomized complete block with three (3) replications. The selected period was characterized by moderate cloud cover and temperature with the following factors; type of cuttings (apical and rejuvenated) and hormone concentration $(0 \mathrm{mg} / \mathrm{L}$ and $10,000 \mathrm{mg} / \mathrm{L})$. The different types of cuttings dipped in different hormone concentration showed significant $(\mathrm{p}<0.05)$ rooting performance. Rejuvenated cuttings dipped in 10,000 $\mathrm{mg} / \mathrm{L}$ of IBA (auxin) rooted best and produced more and long roots. The presence of high $(p<0.05)$ levels of endogenous indole acetic acid, sugars and proteins contributed to the good rooting in the rejuvenated cuttings. Plant nutrients like endogenous zinc and nitrogen in the cuttings also enhanced rooting for the rejuvenated cuttings.
\end{abstract}

Keywords: Vitellaria paradoxa, apical, rejuvenated, indolebutyric acid (IBA), hormone

\section{Introduction}

The shea tree grows naturally in the wild in the dry Savannah belt of West Africa from Senegal in the west to Sudan in the east, and onto the foothills of the Ethiopian highlands. It occurs in 19 countries across the African continent, namely Benin, Ghana, Chad, Burkina Faso, Cameroon, Central African Republic, Ethiopia, Guinea Bissau, Cote D'Ivoire, Mali, Niger, Nigeria, Senegal, Sierra Leone, Sudan, Togo Uganda, Zaire and Guinea. In Ghana, it occurs extensively in the Guinea Savannah and less abundantly in the Sudan Savannah. The Shea tree occurs over almost the entire area of Northern Ghana; an area of about 77,670 square kilometers in Western Dagomba, Southern Mamprusi, Western Gonja, Lawra, Tumu, Wa and Nanumba with Eastern Gonja having the densest stands. There is sparse shea tree cover found in Brong-Ahafo, Ashanti, Eastern and Volta regions in the southern part of the country. Generally, shea trees reach maturity in about 15-20 years (in some cases 40 years) at which point it begins to produce quality nuts and can live up to 200-300 years. However, in managed parklands and areas where bush burning is less rampant the shea trees mature within 6 to 12 years.

The shea nut serves as the main source of livelihood for the rural women and children who are engaged in its gathering. Shea butter is the main edible oil for the people of northern Ghana, being the most important source of fatty acids and glycerol in their diet. It is also used in the pharmaceutical and cosmetic industries as an important raw material and/or a precursor for the manufacture of soaps, candles, and cosmetics. Other important uses include its use as an anti-microbial agent for promotion of rapid healing of wounds, as a pan-releasing agent in bread baking and as a lubricant for donkey carts (Bayala et al., 2002).

Over the last few decades the shea tree densities in parkland have been dwindling. Shea populations are also threatened by the African mistletoe, a parasitic plant. This parasite, which causes discontinued growth, withering of tree parts, and eventual tree death, affects a large portion of the regional shea population. Most parklands are not managed and the tree densities vary between 20 trees/ha to 60 trees/ha. In contrast, managed parkland like that of Cocoa Research Institute of Ghana (CRIG) at Bole in the Northern Region has high tree density ranging between 80-100 trees per hectare. 
The combination of drought, bush fire, population pressure (and the resulting shortened fallows), and climate change have increased tree mortality and removal and decreased tree regeneration increasingly exerting pressure on natural resource use and management. Shea populations are also threatened by the African mistletoe, a plant parasite of the genus Tapinanthus. This parasite, which causes discontinued growth, withering of tree parts, and eventual tree death, affects a large portion of the regional shea population, including $95 \%$ of the trees in Burkina Faso (Lamien et al., 2006). The ecology of the Shea tree including its yield has been well researched (Glele Kakai et al., 2011; Aleza et al., 2018; Bonde et al., 2019). According to these authors, the trees are ravaged by annual bush-fires that usually burn the undergrowth and cause stunted growth of the young trees in the wild. In recent years the shea tree has gained importance as an economic crop because of the heavy demand for its butter, both locally and internationally. In recognition of the need to maximize economic exploitation of the vast shea resource in Ghana, the Cocoa Research Institute of Ghana (CRIG) initiated research into the cultivation and processing of shea nuts. This led to the creation of a subsidiary research station of the CRIG in 1976 at Bole, Northern Ghana. The sole responsibility of the sub-station is to research into the ecology and biology of the shea tree with the aim of improving its growth, performance and yield.

Efforts at domestication require germplasm conservation whilst enhancing the fruit production of the species. The early fruiting of young shea trees over the period ranges from 12 years and beyond which is unattractive to its establishment by farmers. Presently, an acceptable approach used for domesticating endangered tree species is by some vegetative propagation methods which include rooting, air-layering, and grafting (Yeboah et al., 2009; 2011; Akakpo et al., 2014). These methods allow for the production of individuals of the same genetic constitution and also facilitate the multiplication of desirable genotypes in the reproductive phase (Hartmann et al., 2011; Pereira et al., 2016). This is achieved by taking shoots from ontogenetically mature crowns of large trees with the resultant effect of a significant shortening of the juvenile phase (Hackett, 1985; Hartmann et al., 2011). Using these mentioned techniques, fruiting of the shea was observed after 3-4 years when young rooted cuttings and grafted seedlings developed from some desirable trees were transplanted in the field (Yeboah et al., 2009). Also the top working technique which involves cutting down a young shea tree to a height of about $50 \mathrm{~cm}$ and grafting onto the developed shoots with desirable scion fruited 2 - 3 years after grafting (Yeboah et al., 2009). From the observations made, vegetative methods can therefore be used to enhance domestication of the shea tree. Fruiting of the these young shea trees was very consistent as well as a well improved growth. Consequently, the objective of the study is to assess the rooting performance of shea cuttings in relation to hormones, biochemical and nutrient status of cuttings harvested from selected trees.

\section{Materials and Methods}

\subsection{Study Site}

The experiment was carried out from May, 2019 to November, 2019 at the Cocoa Research Institute of Ghana substation at Bole in the Northern region of Ghana, $9^{\circ} 10^{\prime} \mathrm{N}, 2^{\circ} 29^{\prime} \mathrm{W}$. The substation is located in the Interior Savanna agro-ecological zone. The experimental period was characterized by high rainfall (mean rainfall of $102.6 \mathrm{~mm}$ ), high relative humidity (mean humidity of $72.8 \%$ and $69.1 \%$ ) and moderate temperature $\left(29.8^{\circ} \mathrm{C}\right.$; $23.6{ }^{\circ} \mathrm{C}$ ). The area experiences single rainfall maxima with the highest in September followed by June. The months of December and January do not normally record rains and are characterized by high day temperatures and low humidity particularly the month of January (Table 1). 
Table 1. Climatic data, Bole, Ghana 2019

\begin{tabular}{|c|c|c|c|c|c|}
\hline \multirow{2}{*}{ Month } & \multicolumn{2}{|c|}{ Mean Temperature $\left({ }^{\circ} \mathrm{C}\right)$} & \multicolumn{2}{|c|}{ Mean Humidity (\%) } & \multirow{2}{*}{ Total rainfal } \\
\hline & Max. & Min. & $9.00 \mathrm{am}$ & $3.00 \mathrm{pm}$ & \\
\hline January & 35.1 & 20.1 & 30.4 & 20.1 & 0.0 \\
\hline February & 36.6 & 20.5 & 50.1 & 31.0 & 31.8 \\
\hline March & 35.3 & 23.3 & 73.1 & 45.1 & 111.0 \\
\hline April & 34.3 & 22.9 & 76.1 & 59.0 & 105.9 \\
\hline May & 33.3 & 22.8 & 76.5 & 60.6 & 117.3 \\
\hline June & 29.8 & 23.6 & 88.0 & 78.0 & 157.2 \\
\hline July & 29.8 & 23.2 & 78.0 & 71.0 & 121.7 \\
\hline August & 28.6 & 22.1 & 87.5 & 73.4 & 113.6 \\
\hline September & 30.3 & 24.5 & 86.6 & 68.0 & 215.4 \\
\hline October & 32.0 & 22.2 & 82.2 & 59.2 & 78.7 \\
\hline November & 33.8 & 21.6 & 73.2 & 50.7 & 15.9 \\
\hline December & 34.7 & 19.2 & 44.8 & 27.2 & 0.0 \\
\hline
\end{tabular}

\subsection{Experiments}

Three (3) experiments were carried out during the period. One field and two (2) laboratory experiments who involved determination of levels of plant substances and nutrients.

\subsection{Experimental Procedure}

The field experiment (rooting) was conducted to assess the rooting performance of type of cuttings and hormone application. The $2 \times 2$ factorial experiment was arranged in a randomized complete block design with three (3) replicates. The factors considered were; type of cuttings viz; apical/terminal and rejuvenated and hormone concentration viz; $0 \mathrm{ppm}$ and 10,000 ppm. The experiment was set up in the rainy season which is characterized with moderate cloud cover and temperature. The prepared cuttings were arranged in a propagating pit, a rectangular structure with dimensions, $3.0 \mathrm{~m} \times 0.9 \mathrm{~m} \times 0.2 \mathrm{~m}$, topped with moist sterilized rice husk as rooting substrate. The sterilizing was done by loading a truncated drum with the soaked rice husk and filling with water. The content in the drum (rice husk and water) were heated to boiling for one hour (1). The water was drained out of the drum and the husk was poured onto a clean sheet and allowed to cool. The base of the propagating pit was covered with polythene sheet with a space left on the bed to drain out excess water. Medium stones formed the base material followed by gravels $(2 \mathrm{~cm}$ thick on top of the stones). The next level was sharp sand which was spread on the gravel to fill up all the spaces to a thickness of $2 \mathrm{~cm}$ and finally the main medium, sterilized rice husk placed on top to about $15 \mathrm{~cm}$ thick. Placed on the concrete pit with the medium was a metal dome covered with transparent polythene sheet and kept under a shed to provide $50 \%$ shade.

\subsection{Production of the Cuttings}

Apical/terminal cuttings are cuttings which grow at the apex of matured trees as shoots. The new growth is normally softwood and matures to semi-hard wood and hardwood as it ages respectively.

Rejuvenated cuttings develop when the apical meristem is cut/severed (about $10 \mathrm{~cm}$ from the apical meristem) from any branch of the tree. The buds around the tip of the cut branches break after 21 days (depending on the age of the tree) and mature from 45-60 (depending on the tree) days depending on the how lignified (high levels of poly phenyl propane units - a growth inhibitor) the trees are. The initial formed shoots are softwood as it occurs for apical shoots and changes physiologically to semi-hardwood then to hard wood during maturity.

\subsection{Setting of the Cuttings}

The harvested cuttings (softwood and semi-hardwood; $13-15 \mathrm{~cm}$ long) were prepared by pruning off some leaves (leaving the petiole to fall off with time) around the apex and leaving six (6) mature and well developed ones. The base of the prepared cuttings (about $1 \mathrm{~cm}$ long) were dipped in prepared indole butyric acid (IBA an auxin) before setting in the pit propagator. The cuttings were monitored daily to remove infected and dead ones as well as sprayed with fungicide (Dithane M45) at $3,000 \mathrm{mg} / \mathrm{L}$ when there were signs of infection in the structures. Daily watering was done to prevent the leaves of the cuttings from drying and shrinking.

The second experiment involved the determination of some plant substances (level of sugars, phenols, proteins and auxins) and nutrient (level of nitrogen, calcium, zinc and manganese) analysis of the cuttings. 


\subsection{Determination of Levels of Plant Substances}

Sugars and Soluble Proteins were determined by Dubois et al. (1956) and McCready et al. (1950), respectively whilst Total Free Phenols were determined by, Slinkard and Singleton (1977) and Free Auxins by Donate-Correa et al. (2005).

\subsection{Determination of Mineral Nutrient in Cuttings}

One gram (1.0) $\mathrm{g}$ of the plant parts (finely ground and oven dried) was weighed into a digestion tube. To that quantity, $15 \mathrm{~mL}$ of Nitric acid $\left(\mathrm{HNO}_{3}\right)$ was added to digest it. The digesting was done for one extra hour at 200 ${ }^{\circ} \mathrm{C}$. The digested sample in the tube was allowed to cool under fume chamber until no fumes evolved and then filtered through Whatmann No. 42 paper into $250 \mathrm{~mL}$ mark volumetric flask. The solution (filtrate) was topped up with distilled water to the $250 \mathrm{~mL}$ volumetric flask mark and then shaken by hand to ensure a thorough mix of the contents. The concentrations of the elements were determined on an Atomic Absorption Spectrophotometer (AAS)-Spectra AA 220 FS model; Varian Brand.

The content of the element in the plant material was calculated using the formula below (Krachler et al., 2002):

$$
\text { Element }(\mathrm{mg} / \mathrm{kg})=\frac{\text { Concentration read on AAS } \times \text { Final volume after digestion }}{\text { Weight of sample }}
$$

Nitrogen level was determined the by Kjeldhal Method as quoted by Warner and Jones (1967) in Axford (1974).

The parameters studied were: No. of successful rooted cuttings (\%); Length of rooted cuttings; Total number or roots per cuttings; \% levels of auxin, simple sugars, protein and phenol (Plant substances); \% level of nitrogen, calcium, zinc and manganese (Plant nutrients).

Data were collected on the successful rooted cuttings as well as the number of roots and root length. Analysis of variance (ANOVA) was performed on data collected using the Genstat 5 package. The least significant difference (LSD) was used to separate treatment means.

\section{Results}

There was significant $(\mathrm{p}<0.05)$ interactive effect of type of cuttings and indole butyric acid (IBA) concentration on rooting performance. Rejuvenated cuttings developed from coppiced matured trees dipped in 10,000 $\mathrm{mg} / \mathrm{L}$ IBA produced $75.0 \%$ of rooted cuttings, significantly $(\mathrm{p}<0.05)$ greater than the other treatment combinations. The least percentage of rooted cuttings was produced by apical cuttings developed from matured trees without hormone treatment (5.0\%) (Table 2). High callus formation was observed for apical cuttings dipped in 10,000 $\mathrm{mg} / \mathrm{L}$ IBA with the lowest being rejuvenated cuttings.

Table 2. Effect of cutting-type and hormone application on rooting success

\begin{tabular}{llll}
\hline Type of cuttings & $\begin{array}{l}\text { Hormone Application } \\
\text { at } \mathbf{1 0 , 0 0 0 ~} \mathbf{~ m g} / \mathbf{L} \text { IBA }\end{array}$ & Rooting success (\%) & Callus formation (\%) \\
\hline Apical cuttings from matured tree & - & 5.0 & 25.0 \\
\hline Rejuvenated cuttings from coppiced matured tree & - & 35.0 & 35.0 \\
\hline LSD $(5 \%)$ & + & 45.0 & 15.0 \\
\hline
\end{tabular}

Note. -: without hormone; +: with hormone at $10,000 \mathrm{mg} / \mathrm{L}$.

The interaction (type of cutting $\mathrm{x}$ hormone concentration) was significant $(\mathrm{p}<0.05)$ on length of the rooted cuttings. Rejuvenated cuttings developed form coppiced matured trees and dipped in IBA hormone at 10,000 $\mathrm{mg} / \mathrm{L}$ produced 3.0 times longer roots than the apical cuttings which were not dipped in the hormone, whilst the apical cuttings recorded short roots (Table 3a). The same trend occurred for root development in Table $3 \mathrm{~b}$. 
Table 3a. Effect of cutting-type and hormone application on the root length of cuttings

\begin{tabular}{lll}
\hline Type of cuttings & Hormone Application & Root length (cm) \\
\hline Apical cuttings from matured tree & - & 3.5 \\
& + & 5.4 \\
Rejuvenated cuttings from coppiced matured tree & - & 7.8 \\
\hline LSD $(5 \%)$ & + & 14.7 \\
\hline
\end{tabular}

Note. -: without hormone; +: with hormone at $10,000 \mathrm{mg} / \mathrm{L}$.

Table 3b. Effect of cutting-type and hormone application on developed roots

\begin{tabular}{lll}
\hline Type of cuttings & Hormone Application & Developed Roots \\
\hline Apical cuttings from matured tree & - & 2.0 \\
\hline Rejuvenated cuttings from coppiced matured tree & - & 4.0 \\
\hline LSD $(5 \%)$ & + & 8.0 \\
\hline
\end{tabular}

Note. -: without hormone; +: with hormone at $10,000 \mathrm{mg} / \mathrm{L}$.

Apart from the phenol level which was higher (1.7 times greater) in the apical cuttings, the other plant substances in the rejuvenated cuttings contained significantly higher levels. The rejuvenated cuttings contained 1.9 more proteins, 1.2 more simple sugars and 2.2 more auxins than the apical cuttings (Table 4).

Table 4 Level of plant substances in different types of cutting before setting

\begin{tabular}{lllll}
\hline \multirow{2}{*}{ Type of cuttings } & \multicolumn{4}{c}{ Plant Substances } \\
\cline { 2 - 5 } & Protein $(\%)$ & Phenol $(\mathrm{mg} / \mathrm{g})$ & Simple sugar $(\mathrm{mg} / \mathrm{g})$ & Auxin $(\%)$ \\
\hline Apical & 0.7 & 15.7 & 296.1 & 0.25 \\
Rejuvenated & 1.3 & 8.8 & 347.5 & 0.55 \\
\hline LSD (5\%) & 0.4 & 2.5 & 35.7 & 0.2 \\
\hline
\end{tabular}

There was significantly $(\mathrm{p}<0.05)$ high level of zinc and nitrogen for the rejuvenated cuttings whilst calcium and manganese also had high level for the apical cuttings. Calcium and manganese contained 1.6 and 1.5 more levels in the apical cuttings than the rejuvenated cuttings whilst zinc and nitrogen also contained 1.8 and 1.5 more levels in the rejuvenated cuttings than the apical cuttings (Table 5).

Table 5 Level of plant nutrients in different types of cutting before setting

\begin{tabular}{lllll}
\hline \multirow{2}{*}{ Type of cuttings } & \multicolumn{4}{c}{ Plant Nutrients } \\
\cline { 2 - 5 } & Calcium $(\mathrm{Ca})(\%)$ & Zinc $(\mathrm{Zn})(\%)$ & Manganese $(\mathrm{Mn})(\%)$ & Nitrogen $(\mathrm{N})(\%)$ \\
\hline Apical & 1.1 & 1.5 & 1.8 & 1.3 \\
Rejuvenated & 0.7 & 2.7 & 1.2 & 1.9 \\
\hdashline LSD (5\%) & 0.2 & 0.3 & 0.2 & 0.2 \\
\hline
\end{tabular}

\section{Discussion}

Hormone application to cuttings before settings in structures gives interesting results in rooting performance. Rooting of cuttings was better in both the number and length of the roots with the application of $10,000 \mathrm{mg} / \mathrm{L}$ of IBA to rejuvenated cuttings developed from coppiced matured trees as compared to the control. These findings were observed in the anatomy of the rejuvenated shoots treated with IBA at $10,000 \mathrm{mg} / \mathrm{L}$ concentration where discontinuous sclerenchyma cells were observed in the cuttings. Yeboah et al. (2011) recorded similar findings when higher concentrations of IBA $(>5,000 \mathrm{mg} / \mathrm{L})$ were applied to shea stem cuttings. This implies that the greater the concentration of IBA, the better the cell performance and its efficiency of action. The high concentration of soluble protein in the cuttings may be due to the auxin which was used to induce adventitious 
root formation associated with high protein content (Chu et al., 2010). The application of auxin to synergize with endogenous assimilates at the cutting base and to stimulate meristematic differentiation is probably the best-known means of promoting rooting in all kinds of cuttings (Aloni et al., 2006). At cellular level, auxin controls cell division, elongation and differentiation as well as plant cell polarity (Tromas \& Perrot-Rechenmam, 2011). IBA as the best hormone, is very active than IAA in rooting because it does not breakdown easily compared to IAA which is easily attacked and destroyed by the enzyme IAA-oxidase. Indole butyric acid (IBA) does not directly enhance rooting unless it is converted by plant tissues to IAA and immediately absorbed for cellular processes (Hartmann et al., 2011). As a result, high level of IBA can be retained in the plant tissues until it is converted to IAA for cell organization.

The levels of sugar level in the rejuvenated cuttings was higher than the apical cuttings. According to Hartmann et al. (2011), carbohydrate pool of sugars (soluble carbohydrates) and storage carbohydrates (starches or insoluble carbohydrates) are important to rooting as building blocks of complex macromolecules, structural elements, and energy source (Sumaryono et al., 2012). Although the stock plant carbohydrate (sugars) content and rooting may sometimes be positively correlated (Henry et al., 1992; Correa et al., 2005), carbohydrate do not have a regulatory role in rooting. However, they use stored food carbohydrate (sugars) in root development. Husen (2008) observed that once sugar is translocated to the rooting zone of cuttings, it provides the necessary energy for cell division and differentiation at the base of cuttings, and plays an important role in adventitious root formation.

The presence of high levels of protein molecules in the cuttings (rejuvenated cuttings) help in combination with other substances such as phosphorus and carbon to form a complex with a catalytic activity that consequently initiates a developmental sequence resulting in the initiation of cell division to root initiation (Lopez-Bucio et al., 2003; Liu et al., 2018). Also synthesis of protein promotes vascular development (Hartmann et al., 2011) and DNA production to enhance root formation and elongation. This could be the reason why the rejuvenated shoots with high protein content performed better in rooting than the apical cuttings.

Studies have shown that extremely high phenol levels in plants inhibit growth processes (Szecsko et al., 2004; Hartmann et al., 2011). This was observed for the apical cuttings which had high phenol levels contributing to the low rooting success. This high phenol levels (lignification) cause the vascular tissues to be rigid (forming a continuous sclerenchyma cells) thus preventing the penetration of developing roots from the root primordium. The rejuvenated cuttings on the other hand recorded high rooting success because of low phenol levels which was the reverse of the observations made in the apical cuttings.

The importance of nitrogen in root initiation is supported by nutrition studies on rooting of cuttings and the importance of $\mathrm{N}$ in nucleic acid and protein synthesis (Schwambach et al., 2005). The influence of $\mathrm{N}$ on root initiation and development also relates to factors such as carbohydrate availability, $\mathrm{C} / \mathrm{N}$ ratio and hormonal interaction.

Zinc plays a very important role in DNA and RNA metabolism, cell division and protein synthesis which are factors that lead to root formation (Marschner, 1995). It is essential for auxin formation through the biosynthetic pathway which occurs by the promotion of the auxin precursor, tryptophan and the subsequent formation of auxin (IAA) from tryptophan (Hartmann et al., 2011). Plant enzymes activated by zinc are involved in carbohydrate metabolism, protein synthesis and regulation of auxin synthesis. Zinc deficiency significantly affects the root system including root development (Fageria, 2004). The function of zinc could have resulted in high rooting performance of the rejuvenated cuttings.

Manganese and calcium are negatively correlated to rooting $\left(y=115.11-0.993 x ; r^{2}=0.76\right)$. The negative correlation with rooting may be linked to their activation of the IAA- oxidase system and lowering endogenous IAA levels (Jarvis, 1986) which is inhibitory to rooting. The low rooting success of the apical cuttings was a result of the high levels of both nutrients.

\section{Conclusion}

Rooting of shea cuttings can play a major role in parkland development since the growth performance is very rapid and encouraging with early gestation period (four years and beyond). Rejuvenated cuttings harvested from matured shea tree and dipped in $10,000 \mathrm{mg} / \mathrm{L}$ indole butyric acid gave high rooting with more and well-developed long roots. The presence of high levels of auxins, sugars and proteins in rejuvenated cuttings contributed to its high rooting performance with profuse roots. Plant nutrients like zinc and nitrogen also enhanced rooting of the rejuvenated cuttings. 


\section{References}

Akakpo, D. B., Amissah, N., Yeboah, J., \& Blay, E. (2014). Effect of indolebutyric acid and media type on adventitious root formation in sheanut tree (Vitellaria paradoxa C.F. Gaertn) stem cuttings. Amer Jour of Plant Science, 5(3), 313-318. https://doi.org/10.4236/ajps.2014.53043

Aleza, K., Villamor, G. B., Nyarko, B. K., Wala, K., \& Koffi, A. (2018). Shea (Vitellaria paradoxa C.F Gaertn) fruit yield assessment and management by farm households in the Atakora district of Benin. PLoS ONE, 13(1), e0190234. https://doi.org/10.1371/journal.pone.0190234

Aloni, R., Aloni, E., Langhans, M., \& Ullrich, C. I. (2006). Role of cytokinin and auxin in Shaping root architecture: Regulating vascular differentiation, lateral root initiation, root apical dominance and root gravitropism. Annals of Botany, 97(5), 883-893. https://doi.org/10.1093/aob/mcl027

Axford, M. A. (1974). Effect of rootstock and scion on cherry tree mineral nutrition (MSc thesis, Oregon University, USA).

Bayala, J., Teklehaimanot, Z., \& Ouadraogo, S. J. (2002). Millet production under pruned tree crowns in a parkland system in Burkina Faso. Agroforestry Systems, 54, 202-214. htts://oi.org/10.1023/A:101605 8906682

Bondé, L., Ouédraogo, O., Ouédraogo, I., Thiombiano, A., \& Boussim, I. (2019). Variability and estimating in fruiting of shea tree (Vitellaria paradoxa C.F Gaertn.) associated to Climatic conditions in West Africa: implications for sustainable management and development. Plant Production Science, 22(2), 143-158. htts://doi.org/10.1080/1343943X.2018.1541712

Chu, E. P., Tavares, A. R., Kanashiro, S., Giampaoli, P., \& Yokota, E. S. (2010). Effects of auxins on carbohydrates, starch and soluble protein content in Aechmea blanchetiana (Bromeliaceae) cultured in vitro Scientia Hortculturae, 125, 451-455. htts://doi.org/10.1016/j.scienta.2010.04.021

Correa, L. D., Paim, D. C., Schwambach, J., \& Fett-Neto, A. G. (2005). Carbohydrates as regulatory factor on the rooting of Eucalyptus saligna Smith and Eucalyptus globulus Labill. Plant Growth Regulator, 45, 63-73. https://doi.org/10.1007/s10725-004-6125-z

Donate-Correa, J., Leon-Barrios, M., \& Perez-Galdona, R. (2005). Screening for plant-growth rhizobacteria in Chamaecytisus proliferus (tagasaste), a forage tree-shrub legume endemic to the Canary Islands. Plant Soil, 266, 261-72. https://doi.org/10.1007/s11104-005-0754-5

Dubois, M., Gillies, K. A., Hamilton, J. K., Rebers, P. A., \& Smith, F. (1956). Colorimetric method for determination of sugars and related substances. Analytical Chemistry, 28, 350-455 https://doi.org/10.1021/ ac60111a017

Fageria, N. K. (2004). Dry matter yield and nutrient uptake by lowland rice at different growth stages. Journal of Plant Nutrition, 27, 947-958. https://doi.org/10.1081/PLN-120037529

Glele Kakai, R. L., Akpona, T. J. D., Achille, E. A., Gaoue, O. G., Chakeredza, S., Gnangle, P. C., ... Sinsin, B. (2011). Ecological adaptation of the shea tree (Vitellaria paradoxa C.F. Gaertn) along climatic gradient in Benin, West Africa. African Journal Ecology, 49(4), 440-449. https://doi.org/10.1111/j.1365-2028. 2011.01279.x

Hackett, W. O. (1985). Juvenility, maturation and rejuvenation in woody plants. Horticultural Reviews, 7 , 109-155. https://doi.org/10.1002/9781118060735.ch3

Hartmann, H. T., Kester, D. C., Davies, F. T., \& Geneve, R. L. (2011). Plant propagation and practices (6th ed., pp. 279-414). Practice Hall International Editions.

Henry, P. H., Blazich, F. A., \& Hinesley, L. E. (1992). Nitrogen nutrition of containerized eastern cedar. II. Influence of stock plant fertility on adventitious rooting of stem cuttings. J Amer Soc Hort Sci, 117, 568-70. https://doi.org/10.21273/JASHS.117.4.568

Husen, A. (2008). Clonal propagation of Dalbergia sissoo Roxb.and associated metabolic changes during adventitious root primordium development. New Forest, 36, 13-27. https://oi.org/10.1007/s11056007-9079-y

Jarvis, B. C. (1986). Endogenous control of adventitious rooting in non-woody cuttings. In M. B. Jackson (Ed.), New root formation in plants and cuttings (pp. 191-222). Martinus Nijhoff Publishers, Dordrecht, Netherlands. https://doi.org/10.1007/978-94-009-4358-2_6 
Krachler, M., Mohl, C., Emons, H., \& Shotyk, W. (2002). Anatylical procedures for the determination of selected trace elements in peat moss and plant substances by Inductively Coupled Plasma Mass Spectrometry. Spectrochemica Acta, Part B, 57, 1277-1289. https://doi.org/10.1016/S0584-8547(02) 00068-X

Lamien, N., Boussim, J. I., Nygard, R., Ouedraogo, J. S, Oden, P. C., \& Guinko, S. (2006). Mistletoe impact on Shea tree (Vitellaria paradoxa C.F. Gaertn.) flowering and fruiting behavior in Savanna area from Burkina Faso. Environmental and Experimental Botany, 55(1), 142-148 https://doi.org/10.1016/j.envexpbot. 2004.10.010

Liu, A., Contador, C. A., Fan, K., \& Lam, H. M. (2018). Interaction and Regulation of carbon, Nitrogen and Phosphorus Metabolism in Root Nodules of Legumes. Front Plant Sci, 9, 1860. https://doi.org/10.3389/ fpls.2018.01860

Lopez-Bucio, J., Cruz-Ramirez, A., \& Herrera-Estrella, L. (2003). The role of nutrient availability in regulating architecture. Current Opinion in Plant Biology, 6(3), 280-287. https://doi.org/10.1016/S1369-5266(03) 00035-9

Marschner, H. (1995). Mineral nutrition in higher plants (pp. 347-364). Academia Press, New York. https://doi.org/10.1016/B978-012473542-2/50008-0

McCready, R. M., Guggoiz, J., Silveria, V., \& Owens, H. S. (1950). Determination of starch and amylase in vegetables. Anal Biochem, 22, 1556-58. https://doi.org/10.1021/ac60045a016

Pereira, F. M., Usman, M., Mayer, N. A., Nachtigal, J. C., Ranny, O., Mbongeni, M., \& Willemse, S. (2016). Advances in guava propagation. Rev Bras Frutic, 39(4), 39-43. https://doi.org/10.1590/0100-29452017358

Schwambach, J., Fadanelli, C., \& Fett-Neto, A. G. (2005.) Mineral nutrition and adventitious rooting in micro cuttings of Eucalyptus globulus. Tree Physiology, 25(4), 487-494. https://doi.org/10.1093/treephys/25.4.487

Slinkard, K., \& Singleton, V. L. (1977). Total phenol analysis: Automation and comparison with manual methods. Am J Enol Vitic, 41, 1179-85.

Sumaryono, S., Muslihatin, W., \& Ratnadewi, D. (2012). Effect of Carbohydrate Source on Growth and Performance of in vitro Sago Palm (Metroxylon sagu Rottb.) Plantlets. Hayati Journal of Biosciences, 19(2), 88-92. https://doi.org/10.4308/hjb.19.2.88

Szecskó, V., Hrotko, K., \& Stefanovits-Bányai, É. (2004). Phenolic compounds, bud dormancy, and rooting ability of plum hardwood cuttings. Acta Horticulturae, 679-687. https://doi.org/10.17660/ActaHortic. 2004.658.104

Tromas, A., \& Perrot-Rechenmann, C. (2010). Recent progress in auxin biology. Comptes Rendus Biologies, 333, 297-306. https://doi.org/10.1016/j.crvi.2010.01.005

Warner, M. H., \& Jones, J. B. (1964). Determination total nitrogen in plant tissues using a Technicon Kjeldahl nitrogen apparatus. Symp Automation Anal Chem, 1, 145-148.

Yeboah, J., Lowor, S. T., \& Amoah, F. M. (2009). The rooting performance of sheanut (Vitellaria paradoxa C.F. Gaertn) cuttings leached in water and application of rooting hormone in different media. Jour of Plant Sci, 4(1), 10-14. https://doi.org/10.3923/jps.2009.10.14

Yeboah, J., Lowor, S. T., Amoah, F. M., \& Owusu-Ansah, F. (2011). Propagation structures and some structures and some factors that affect the rooting performance of sheanut (Vitellaria paradoxa C.F. Gaertn) cuttings. Agric Biol J of North Amer, 2(2), 258-269. https://doi.org/10.5251/abjna.2011.2.2.258.269

\section{Copyrights}

Copyright for this article is retained by the author(s), with first publication rights granted to the journal.

This is an open-access article distributed under the terms and conditions of the Creative Commons Attribution license (http://creativecommons.org/licenses/by/4.0/). 